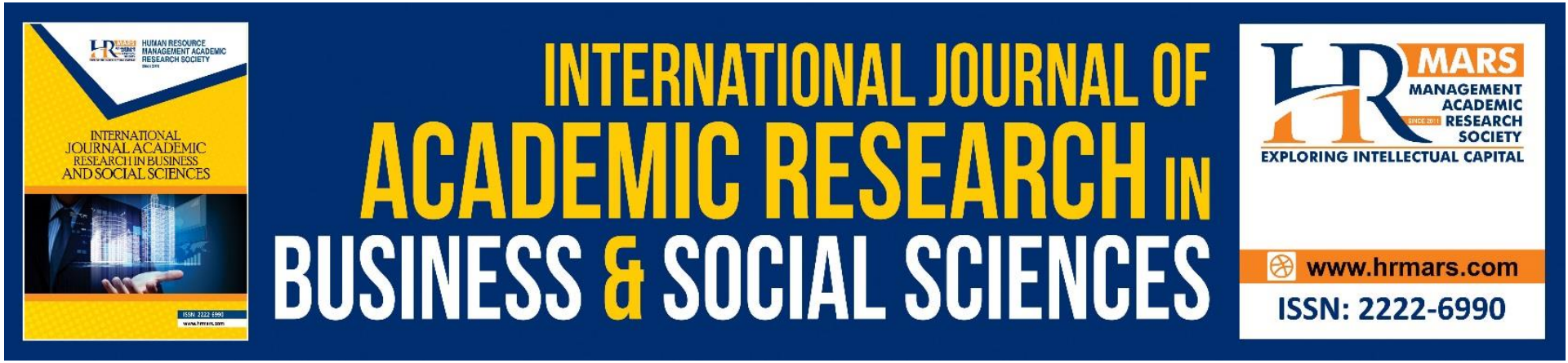

\title{
A Study of Urban Living Skills Among Multi- Ethnic Youth in Malaysia
}

\section{Mohd Ariffuddin bin Kamari, Abdul Razaq Ahmad}

To Link this Article: http://dx.doi.org/10.6007/IJARBSS/v11-i3/9097

DOI:10.6007/IJARBSS/v11-i3/9097

Received: 07 January 2021, Revised: 04 February 2021, Accepted: 28 February 2021

Published Online: 26 March 2021

In-Text Citation: (Kamari \& Ahmad, 2021)

To Cite this Article: Kamari, M. A. bin, \& Ahmad, A. R. (2021). A Study of Urban Living Skills Among Multi- Ethnic Youth in Malaysia. International Journal of Academic Research in Business and Social Sciences, 11(3), 10471060.

\section{Copyright: (c) 2021 The Author(s)}

Published by Human Resource Management Academic Research Society (www.hrmars.com)

This article is published under the Creative Commons Attribution (CC BY 4.0) license. Anyone may reproduce, distribute, translate and create derivative works of this article (for both commercial and non-commercial purposes), subject to full attribution to the original publication and authors. The full terms of this license may be seen

at: http://creativecommons.org/licences/by/4.0/legalcode

Vol. 11, No. 3, 2021, Pg. 1047 - 1060

Full Terms \& Conditions of access and use can be found at http://hrmars.com/index.php/pages/detail/publication-ethics 


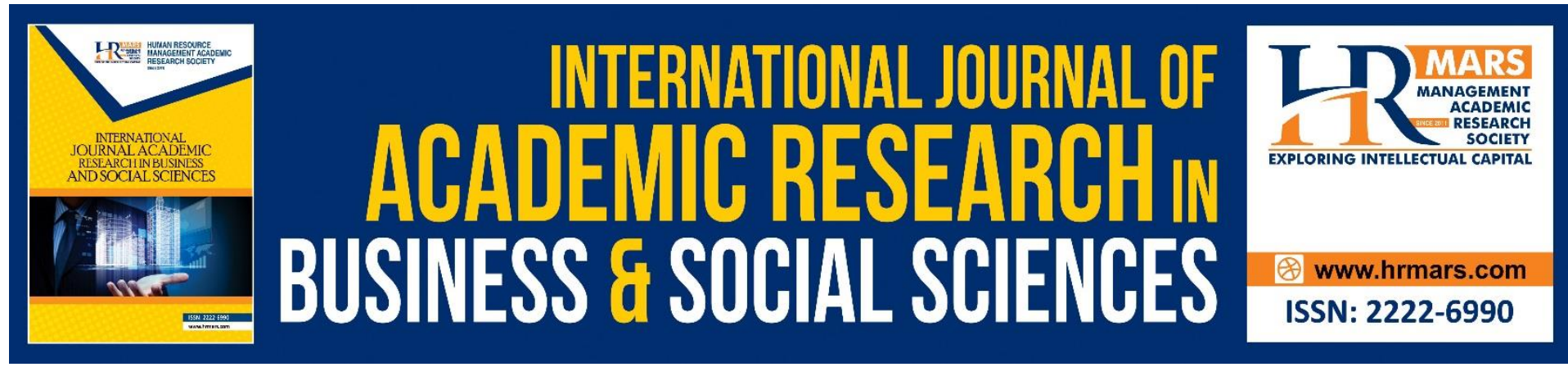

\title{
A Study of Urban Living Skills Among Multi- Ethnic Youth in Malaysia
}

\author{
Mohd Ariffuddin bin Kamari, Abdul Razaq Ahmad \\ Faculty of Education, National University of Malaysia \\ Email: razaq@ukm.edu.my
}

\begin{abstract}
The increase in the rural population moving to the City has put pressure on the population patterns and structures especially in the City. Therefore, survival skills strategies are considered effective in dealing with negative behaviour problems among youth while helping them to face various challenges positively. Survival skills are one of the aspects that need to be taken into account in achieving the quality of life of youth in the City. Thus, this study aims to identify survival skills of urban youth in-terms of their knowledge in urban living, urban life skills, involvement in life long learning and their values as well as living culture in urban life based on gender and ethnicity. This study uses quantitative study design using survey method. A total of 2400 youths were selected using the stratified random sampling method. The instrument of this study is a questionnaire that has been adapted and has been referred to several experts to determine the validity of criteria, content and language. A pilot study was conducted and showed the items were at a high level of reliability with Cronbach Alpha values of 0.834 to 0.929 . The findings show that there is no significant difference in survival for aspects of knowledge about urban life, urban life skills, lifelong learning as well as values and culture of urban living based on gender and ethnicity. The findings also show a significant effect of interaction between gender and ethnicity of survival skills on aspects of knowledge about life, life skill, lifelong learning as well as the values and culture of living in the City. Relevant parties need to improve survival skills by planning and designing appropriate programs taking into account gender and ethnic aspects to ensure that these programs can be used in various genders and ethnicities of youth.
\end{abstract}

Keywords: Survival, Youth, Gender, Ethnicity, Urban

\section{Introduction}

The increase in the rural population moving to the City has put pressure on the population patterns and structures especially in the City. Youth is the most populous category and contributes to the transfer of population from rural to urban. Nor Ermawati et al., (2015) stated that among the factors that cause the transfer of youth to major and major cities in Malaysia are employment opportunities, educational facilities, more comprehensive social services such as medicine and transportation. Youths who migrate to the City aim to find employment opportunities to improve their quality of life. Apart from that, this group also aims to further their studies or gain skills. 
This process puts them under pressure in terms of education, health facilities and employment (Usman \& Tarmiji, 2010). In addition, youth also contribute to various social problems caused by factors such as stress, frustration and peer influence in the City (Roslee $\&$ Dzulkiflee, 2008). Youth are often seen as a risky group and tend to be involved in unhealthy symptoms (Samsudin, 2007; Fazilah et al., 2008). Fernandes-Alcantera (2012) thinks that youth are considered at risk because they have economic constraints and barriers to employment. While Samsudin (2007) argues that youths who feel depressed and desperate with uncertain future conditions will be involved in negative behavior and are considered as those who have high risk in triggering various social problems to become a burden to society and the country.

According to the EACEA report, the European Commission, (2013) employment status is also a threat to the well-being of youth. The report also stated that poverty and unskilled contract employment and low income will make the youths face various other problems. These include having a quality home, material security, quality education and training, good health care, recreational activities, as well as getting professional counseling in the event of emotional problems. Lack of opportunities to get a job results in psychological discomfort that leads to feelings of inferiority and confidence (Dolly and Kamsiah, 2018). This condition in turn will affect the individual's personal health. Poverty affects the quality of life. With no education and employment, this has the effect of long-term marginalization of youth in social and political aspects which in turn increases feelings of dependence, powerlessness and coping. Without employment, education and training pose a risk to unhealthy behaviors, contributing to severe health conditions and further social isolation (EACEA, European Commission, 2013).

The increasing urban population is also seen as a result of deviant policies by the government (Siwar, et al., 2016). The introduction to policies that focus on youth development in the City should be a concern for the government. This is because the youths are one of the endangered groups (Nor Azrul, 2019). Therefore, survival skills strategies are considered effective in dealing with negative behavior problems among youth while helping them to face various challenges positively. Argent and Walmsley (2008) argue that survival skills are one of the aspects that need to be considered in achieving the quality of life of youth in the City. Sangeeta and Bhamimi (2012) stated that survival skills can increase economic needs and social interaction among youth. Thus, this study aims to identify survival skills based on gender and ethnicity among urban youth. Survival skills are viewed from the aspect of knowledge about life in the City, life skills in the City, lifelong learning as well as the values and culture of living in the City.

\section{Literature Review}

In complex and dynamic community situations such as in urban areas, youth need to be an individual who has the knowledge and wisdom to use all the strength to stand out and compete positively to continue to survive and contribute to society. Each individual needs to meet the needs and demands by ensuring that basic needs can be met, while all knowledge and skills can be shared to place roles and influence to the community and society.

The change of society from a homogeneous and moderate group to a more complex level of modern society requires high self-adjustment and adaptation in order to understand 
the different contexts of society. Spencer (1976) applies the concept that those who are strong will win while those who are weak will fail to compete for survival. He is of the view that agile, efficient and productive individuals will be able to overcome the challenges and continue the struggle of life while those who are lazy, weak and quickly break the foundation will be excluded and will not be able to compete in a very challenging living environment in urban and urban areas.

Research related to survival skills has been conducted such as a study conducted by Usman and Tarmiji (2010) found that youths who move to the city center in Malaysia are often faced with problems related to basic facilities. Samsudin's (2007) study found that marginalized youths will feel their future is bleak when not given skills and motivation.

A study conducted by Catalano et al., (2004) in North America found that $96 \%$ of the survival skills possessed by youth can reduce social problems. Meanwhile in Hong Kong, Shek (2010) found that youths who have positive behavior have a significant relationship with social problems among Chinese youths.

Several studies have found that survival skills have a negative relationship with sexual misconduct (Desousa et al., 2008; Puspakumarag, 2013), violence (MacDonald et al., 2005) and drug abuse (Desousa et al., 2008). In previous studies, some studies used survival skills as independent variables (Gebauer et al., 2008), as predictors (Heisel and Flett, 2004), while several other studies determined the influence of survival skills on social problems ( McKnight et al., 2002; Suldo and Huebner, 2004).

Rajib Acharya et al., (2009) conducted a study of survival skills among female youth. The study of Ramesht and Farshad C. (2004) proved the effectiveness of survival skills in improving mental and physical health, positive behavior and reducing social problems. Roodbari et al., (2013) in their study showed that survival skills can have a positive influence in enhancing the social and emotional development of youth.

\section{Research Purpose}

This study aims to identify survival skills of urban youth in-terms of their knowledge in urban living, urban life skills, involvement in life long learning and their values as well as living culture in urban life based on gender and ethnicity.

\section{Methodology}

\section{Sample}

The study respondents consisted of 2400 youths from Kuala Lumpur - the Capital City of Malaysia. A total of 1123 respondents (46.8\%) were male youths and 1277 respondents (53.2\%) were female youths. A total of 1133 respondents (47.2\%) were Malay and 1267 respondents (52.8\%) were non-Malay youths. A total of 1424 people (59.3\%) were youths aged less that 25 years, 744 respondents (31.0\%) aged between 26 and 30 , and 232 respondents (9.7\%) were aged 31 years and over. The samples were selected using a simple stratified random sampling method. 


\section{Instrument}

The instrument of this study uses a questionnaire that has been adapted from the theory of Spencer (1976) and modified from Simon Herthnon (2005). This questionnaire has also been referred to several experts to assess the validity of the criteria, content and language. A pilot study was also conducted to determine the value of reliability and the findings of the pilot study showed that the item was at a high level of reliability with a Cronbach Alpha value of 0.834 to 0.929 . This questionnaire is divided into several parts, namely: Part A Demographics (9 items); Part B Knowledge in Urban life (9 items); Part C Urban life skills (9 items); Part D Lifelong learning (5 items) and Part E Urban cultural values (8 items).

\section{Data Analysis}

The data analysis of this study uses inferential statistics that refer to the Two-Way MANOVA analysis to identify differences in survival skills based on gender and ethnicity among urban youth. Prior to this analysis, the researchers first ascertained and confirmed whether there were multivariate outliers on the data based on the value of Mahalanobis Distances, conducted normality tests to determine the distribution of items and homogeneity tests to determine the homogeneity of the variants involved.

\section{Findings}

The survival variables consist of four aspects or sub-constructs namely knowledge in urban life, urban life skills, lifelong learning and values and ethics of urban living. Comparisons of these four variables based on gender and ethnicity were made using the Two-Way MANOVA test.

Before a two-way MANOVA analysis is carried out, the researchers first ascertain and confirm whether there are multivariate outliers on the data based on the value of Mahalanobis Distances. The maximum value of Mahalanobis Distances obtained is 35.64. According to Pallant (2001), the maximum value of Mahalanobis Distances for three independent variables must not exceed 18.47. Thus, it was found that there are 36 respondents belong to multivariate outliers and released in this study. The actual analysis involved 2364 respondents.

Researchers also first determine the homogeneity of the variance-covariance matrics using the Box's $M$ test. This Box's $M$ test is important to determine whether the variancecovariance among the dependent variables is the same or vice versa, across all independent variables. This is an important pre-requisite for the MANOVA test. The MANOVA test assumes that the variance-covariance among the dependent variables is the same, across all independent variables (Hair et al., 2010). Table 1 shows the results of Box's M test.

Table 1 Box's M Test

\begin{tabular}{ccccc}
\hline Box's M & F-Value & Freedom of Degree 1 & Freedom of Degree 2 & Sig. Level \\
\hline 60.025 & 1.995 & 30 & 1448654.999 & $0.001^{* *}$ \\
\hline
\end{tabular}

Based on Table 1, it was found that there was a significant variance-covariance among the dependent variables for all levels of the independent variables $(F=1.995, p=$ $0.001)(p<0.05)$. This means, the covariant variant-covariance of non-homogeneous 
variables across all independent variables. In this case, although the variance-covariance homogeneity matrix (Box's $M$ test) is significant, it is not a problem for MANOVA test if the sample size is large and almost the same (largest sample / smallest sample $<1.5$ ) due to the effect of type I error (type I error) is very small. In this study, the number of samples is large and almost the same, therefore testing of the above hypothesis can be done using MANOVA test. The results of the Two-Way MANOVA analysis are as in Table 2.

Table 2 Two-Ways MANOVA Analysis Differences in Life Survival based on Gender and Ethnic

\begin{tabular}{lccccc}
\hline \multicolumn{1}{c}{ Effect } & $\begin{array}{c}\text { Wilks' } \\
\text { Lamda } \\
\text { Value }(\boldsymbol{\lambda})\end{array}$ & F-Value & $\begin{array}{c}\text { DF in } \\
\text { between } \\
\text { group }\end{array}$ & DF in group & $\begin{array}{c}\text { Sig. } \\
\text { Level }\end{array}$ \\
\hline $\begin{array}{l}\text { Gender } \\
\text { Ethnic }\end{array}$ & 0.999 & 0.721 & 4 & 2360 & 0.577 \\
$\begin{array}{l}\text { Interaction } \\
\text { Gender*Ethnic }\end{array}$ & 0.996 & 2.266 & 4 & 2360 & 0.060 \\
\hline
\end{tabular}

Based on Table 2, it is found to compare the mean scores of knowledge in urban life, urban life skills, lifelong learning and values and ethics of urban living based on gender, Wilks' $\lambda$ value $=0.999, F(4,2360)=0.721$ and $p=0.577(p>0.05)$. For a comparison of mean scores of knowledge in urban life, urban life skills, lifelong learning and values and ethics of urban living based on ethnicity, Wilks' $\lambda$ value $=0.996, F(4,2360)=2.266$ and $p=0.060(p>0.05)$. As for the effect of interaction between gender and ethnicity on knowledge support in urban life, urban life skills, lifelong learning and values and ethics of urban life, Wilks' $\lambda=0.989, F(4$, $2364)=6.435$ and $p=0.001(p<0.05)$.

Next, multiple ANOVAs analysis was performed to see the difference in mean score for each dependent variable, namely knowledge in urban life, urban life skills, lifelong learning and values and ethics of urban living based on gender and ethnicity as an extension of MANOVA Two analysis -Hala. To control the type I error for this multiple test, the Bonferroni test was used and each ANOVA was tested at a significant level of 0.025 (Green et al. 1997). Tables 3 and 4, show the results of ANOVA analysis for the mean score differences of each dependent variable namely knowledge in urban life, urban life skills, lifelong learning and values and ethics of urban living based on gender and ethnicity. 
INTERNATIONAL JOURNAL OF ACADEMIC RESEARCH IN BUSINESS AND SOCIAL SCIENCES Vol. 11, No. 3, 2021, E-ISSN: 2222-6990 @ 2021 HRMARS

Table 3 Min and Standard Deviation Differences in Life Survival based on Gender and Ethnic

\begin{tabular}{|c|c|c|c|c|c|}
\hline Aspect & $\begin{array}{c}\text { Gender } \\
\text { Respondent }\end{array}$ & Ethnic & Min & S. Dev & V \\
\hline \multirow[t]{9}{*}{ Knowledge in Urban Living } & Male & Malay & 3.466 & 0.715 & 550 \\
\hline & & Non Malay & 3.514 & 0.724 & 554 \\
\hline & & Total & 3.490 & 0.719 & 1104 \\
\hline & Female & Malay & 3.494 & 0.724 & 570 \\
\hline & & Non Malay & 3.499 & 0.663 & 693 \\
\hline & & Total & 3.497 & 0.691 & 1263 \\
\hline & Total & Malay & 3.481 & 0.719 & 1120 \\
\hline & & Non Malay & 3.506 & 0.691 & 1247 \\
\hline & & Total & 3.494 & 0.704 & 2367 \\
\hline \multirow[t]{9}{*}{ Urban Life Skills } & Male & Malay & 3.567 & 0.718 & 550 \\
\hline & & Non Malay & 3.504 & 0.834 & 554 \\
\hline & & Total & 3.535 & 0.779 & 1104 \\
\hline & Female & Malay & 3.498 & 0.826 & 570 \\
\hline & & Non Malay & 3.522 & 0.767 & 693 \\
\hline & & Total & 3.511 & 0.794 & 1263 \\
\hline & Total & Malay & 3.532 & 0.775 & 1120 \\
\hline & & Non Malay & 3.514 & 0.797 & 1247 \\
\hline & & Total & 3.523 & 0.787 & 2367 \\
\hline \multirow[t]{9}{*}{ Life Long learning } & Male & Malay & 3.620 & 0.615 & 550 \\
\hline & & Non Malay & 3.592 & 0.689 & 554 \\
\hline & & Total & 3.606 & 0.653 & 1104 \\
\hline & Female & Malay & 3.537 & 0.640 & 570 \\
\hline & & Non Malay & 3.676 & 0.639 & 693 \\
\hline & & Total & 3.613 & 0.643 & 1263 \\
\hline & Total & Malay & 3.578 & 0.629 & 1120 \\
\hline & & Non Malay & 3.639 & 0.663 & 1247 \\
\hline & & Total & 3.610 & 0.648 & 2367 \\
\hline \multirow{9}{*}{$\begin{array}{l}\text { Value and Culture Living } \\
\text { in Urban Life }\end{array}$} & Male & Malay & 3.681 & 0.686 & 550 \\
\hline & & Non Malay & 3.689 & 0.691 & 554 \\
\hline & & Total & 3.685 & 0.688 & 1104 \\
\hline & Female & Malay & 3.692 & 0.725 & 570 \\
\hline & & Non Malay & 3.705 & 0.717 & 693 \\
\hline & & Total & 3.699 & 0.720 & 1263 \\
\hline & Total & Malay & 3.687 & 0.706 & 1120 \\
\hline & & Non Malay & 3.698 & 0.705 & 1247 \\
\hline & & Total & 3.693 & 0.705 & 2367 \\
\hline
\end{tabular}


Table 4 ANOVA Test Differences in Life Survival based on Gender and Ethnic

\begin{tabular}{|c|c|c|c|c|c|c|c|}
\hline $\begin{array}{c}\text { Dependent } \\
\text { Variable }\end{array}$ & Main Effect & J.K.D. & D.F. & M.K.D. & $\begin{array}{c}\text { F- } \\
\text { Value }\end{array}$ & Sig. & $\begin{array}{c}\text { Eta } \\
\text { Square }\end{array}$ \\
\hline Knowledge in & Gender & 0.028 & 1 & 0.028 & 0.056 & 0.812 & 0.000 \\
\hline \multirow[t]{5}{*}{ Urban Living } & $\begin{array}{c}\text { Ethnic } \\
\text { Interaction }\end{array}$ & 0.397 & 1 & 0.397 & 0.799 & 0.372 & 0.000 \\
\hline & Gender* & 0.267 & 1 & 0.267 & 0.538 & 0.463 & 0.000 \\
\hline & Ethnic & 1174.645 & 2363 & 0.497 & & & \\
\hline & Error & 1175.300 & 2366 & & & & \\
\hline & Total & & & & & & \\
\hline \multirow[t]{7}{*}{ Urban Life Skills } & Gender & 0.378 & 1 & 0.378 & 0.609 & 0.435 & 0.000 \\
\hline & Ethnic & 0.234 & 1 & 0.234 & 0.378 & 0.539 & 0.000 \\
\hline & Interaction & & & & & & \\
\hline & Gender* & 1.107 & 1 & 1.107 & 1.786 & 0.182 & 0.000 \\
\hline & Ethnic & 1465.338 & 2363 & 0.620 & & & \\
\hline & Error & 1466.964 & 2366 & & & & \\
\hline & Total & & & & & & \\
\hline Life Long & Gender & 3.9025 & 1 & 3.9025 & 0.000 & 0.992 & 0.000 \\
\hline \multirow[t]{5}{*}{ learning } & Ethnic & 1.806 & 1 & 1.806 & 4.320 & 0.038 & 0.000 \\
\hline & Interaction & & & & & & \\
\hline & Gender*Ethnic & 4.083 & 1 & 4.083 & 9.768 & 0.002 & 0.004 \\
\hline & Error & 987.778 & 2363 & 0.418 & & & \\
\hline & Total & 994.060 & 2366 & & & & \\
\hline Value and Life & Gender & 0.102 & 1 & 0.102 & 0.204 & 0.652 & 0.000 \\
\hline \multirow[t]{5}{*}{ Ethic in the City } & Ethnic & 0.064 & 1 & 0.064 & 0.128 & 0.721 & 0.000 \\
\hline & Interaction & & & & & & \\
\hline & Gender*Ethnic & .002 & 1 & 0.002 & 0.005 & 0.946 & 0.000 \\
\hline & Error & 1178.816 & 2363 & 0.499 & & & \\
\hline & Total & 1178.9965 & 2366 & & & & \\
\hline
\end{tabular}

Based on Table 4, it was found that there was no significant difference in terms of knowledge in urban life $(F(1,2363)=0.056, p=0.812 ; p<0.025)$ based on gender. This means that knowledge in urban life among male and female youths is at the same level which is a moderate level (male mean $=3.490$; female mean $=3.497$ ).

In terms of ethnicity as well, it was found that there was no significant difference in terms of knowledge in urban life $(F(1,2363)=0.799, p=0.372)$ based on ethnicity. This means the knowledge of life in the city among the youth Malay and non-Malay youths are at the same level of moderate level (mean $=3,481$ wither; mean not wither $=3,506$ ).

A comparison of urban life skills based on gender, however, showed that there was no significant difference in terms of urban life skills based on gender $(F(1,2363)=0.609, p=$ $0.435 ; p>0.25)$ ). This means that urban life skills among male and female youths are at the same level which is at a moderate level (male mean $=3.535$; female mean $=3.511$ ).

Comparison of urban life skills based on race as well, showed that there was no significant difference in terms of urban life skills based on ethnicity $(F(1,2363)=0.378, p=$ 
$0.359 ; p>0.025)$. This means life skills among youth in the city of Malay and non-Malay youths are at the same level that is at a moderate level (mean Malay $=3,532$; mean not wither $=$ $3,514)$.

From the aspect of lifelong learning, it was found that there was no significant difference in terms of lifelong learning based on gender $(F(1,2363)=0.000, p=0.992)$. This means that lifelong learning among male and female youths is also at the same level which is at a moderate level (male mean $=3.606$; female mean $=3.613$ ).

In terms of ethnicity, it was also found that there was no significant difference in terms of lifelong learning $(F(1,2363)=4.320, p=0.038 ; p>0.025)$ based on ethnicity. It means lifelong learning among the youth of Malay and non-Malay youths are at the same level which is at a high level (min Malay = 3578; mean not wither $=3.639$ ).

In terms of values and ethics of urban living, it was found that there is no significant difference in terms of values and ethics of urban living based on gender $(F(1,2363)=0.204$, $p=0.6520$. This means values and ethics of urban living among male and female youth are at the same level i.e. high level (mean male $=3.685$; mean female $=3.699$ ).

In terms of ethnicity, it was also found that there was no significant difference in terms of values and ethics of urban life $(F(1,2363)=0.128, p=0.721)$ based on ethnicity. This means that the values and ethics of life in the city among the youth Malay and non-Malay youths are at the same level which is at a high level ( $\min$ Malay $=3,687$; mean not wither $=3,698$ ).

Based on Table 4 as well, it was found that there is no significant interaction effect between gender and ethnicity on knowledge in urban life $(F(1,2367)=0.538, p=0.463)$, urban life skills $(F(1,2363)=1.786, p=0.182)$ and values and ethics of urban life $(F(1,2363)=$ $0.005, p=0.946$ ) among youths in Kuala Lumpur City.

However, there was a significant effect of interaction between gender and ethnicity on lifelong learning $(F(1,2363)=9.768, p=0.002 ; p<0.025)$. The graph of interaction between gender and ethnicity over lifelong learning is as shown in Figure 1.

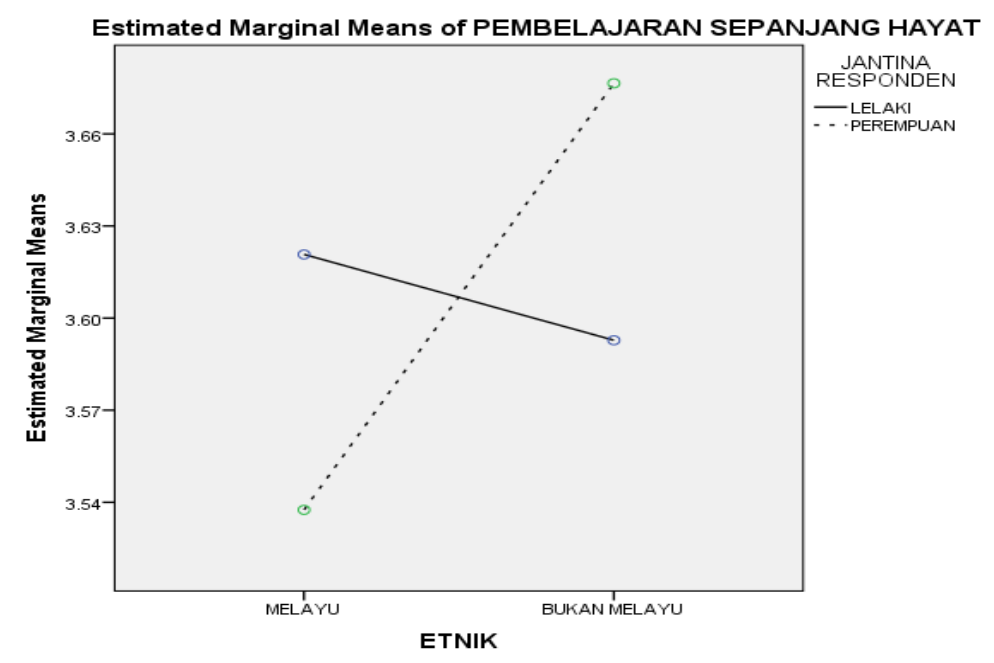

Diagram 1 Graf Interaction between Gender and Ethnic towards Life Long Learning 
This finding clearly shows that among youth wither, the level of lifelong learning for young males (mean $=3,620$ ) is higher than this young woman (mean $=3,537$ ), while for youth non-Malays, the level of lifelong learning, youth, women (mean $=3.676$ ) was higher than male youth $($ mean $=3.592)$.

\section{Discussions}

The results show that there is no difference between knowledge in urban life, urban life skills, lifelong learning and values and ethics of urban living based on gender. This shows that young men and women have the same level of survival to live in the city. Both male and female youths show at the same level i.e. moderate.

The results of previous studies from (Saenz et al., 2007) also stated that today's youth, regardless of gender, need some basic skills in Lifelong Learning such as self-management, communication, managing others and themselves, as well as the ability to adapt to any changes and new things. Lifelong learning is an effort to find a way out, voluntary and motivated for knowledge not only for personal reasons but also professional (Ates \& Alsal, 2012). A study conducted in Nepal by Gautam (2016) which aims to identify the importance of soft skills among urban youth to prepare themselves towards career opportunities at home or abroad. The majority of urban youths pursue formal education from colleges and universities in Nepal. This is to prepare themselves for the job market as well as a good quality of life after graduation.

In terms of ethnicity, the results show that there is no difference in terms of knowledge in urban life, urban life skills, lifelong learning and values and ethics of urban living among urban youth. This shows that multiracial youths have an open mind to stay alive in urban areas. Whereas (Mustari, 2005) considers successful youth is when they can determine the direction of the future with good preparation and the right action to ensure future success. Education is one of the aspects that need to be emphasized. Education is a catalyst for a more prosperous human life towards a more perfect life, management wisdom in the management of the family economy, authority in human relationships as well as physical, mental and spiritual balance.

Furthermore, this study found that there is no significant interaction between gender and ethnicity on knowledge in urban life and values and ethics of urban living among youths in Kuala Lumpur City. Findings show the level of knowledge and understanding of youths in urban areas that are at a high level in some dimensions that symbolize the manifestation of aspects of religious thought (religious thought) and belief (religious belief) in their Islamic religion (Islamic religiosity). Studies also show that there is a positive relationship between the level of education and Islamic religious thought. Such shows that the level of education and exposure to religious activities affect religious thinking (Mashitah et al., 2018).

The results show that there is a significant effect of interaction between gender and ethnicity on lifelong learning. These findings clearly show that among Malay youths, the level of lifelong learning for young males is higher than that of young women, while for non-Malay youths, the level of lifelong learning, youth, women are much higher than young men. The findings of this study indicate that gender and ethnicity affect lifelong learning. This is because among the youth, knowledge can be obtained anywhere regardless of gender and ethnicity. 
The priority is to come from the knowledge you have. This awareness arises because the youth of the city have a high level of desire and curiosity. Where every change that occurs youth in the city is faster and more aggressive in seeking information (M. M. Alsubaie et al., 2019).

The findings of Lam et al., (2012) related to gender differences in the achievement of school students in 12 countries also support the findings of Mohd Jelas et al., (2005) who showed that the achievement of female students is higher than male students. This is due to the style and skills of female students who are found to be appropriate to the way teachers teach and how to prepare themselves before facing exams (Mohd Jelas et al., 2005; Lam et al., 2012). Female students also rely more on their peers to assist them in learning activities (Mohd Jelas et al., 2014; Lam et al., 2012).

\section{Contribution of Study}

This study provides information that survival in urban living aspect is an important mediator between social ecological support and quality of life among youths in the city. This directly shows that individuals' knowledge, skills, lifelong learning participation, noble values practices and productive cultural are key pillars of social ecological support enhancement towards quality of life in the city. This means that the existing social ecological support among urban community is still unable to improve the quality of life in challenging urban areas. Indeed, survival in urban life has close link with types of social ecological support received by urban communities. Therefore, to survive in urban life, everyone should have good living skills as it is an important factor that will improve a quality of life, especially among urban youth. There is rich data from this study to prove that social ecological support factors and survival living skills are the inter-connected factors that are contributing to the quality of urban life. It becomes a keyword for urban youth to improve the quality of life. This indicates the importance of strategic planning in various aspects in knowledge activities, skills, lifelong learning participation, noble values practices and productive cultural as initiatives order to improve the quality of life among diverse background of youth population. It helps them to enhance their life well-being in the city.

This study also provides input to various parties in making various plans in both physical development and or socio-economic improvement to enhance the quality of life among urban population. With these empirical inputs, stakeholders can make plans to make developments in accordance with the needs of various communities in the city. The results of this study can also help various parties including authority bodies and policy makers to be aware of current issues and problems faced by the urban community. Thus, results from this study provide evidence input from ground for further attention. It is clear from this study that a combination of bottom-up and top-down strategies are needed to ensure the quality of urban planning for improving urban community well-being.

The current study provides a proof that male and female youth in urban require similar basic survival skills to face challenges of urban life. This is because urban communities are supposed to have better self-management, communication skills and adaptation abilities to me them always relevant in urban socio-economic environment. Urban communities have been exposed into rapid various socio-economic changes due to global changes. There are so many new skills require to get survived in urban life such as virtual technological skills, interpersonal cross cultural negotiation, smart decision making and abilities to predict market 
needs. Global economic changes have resulted in many new technological invention that affect conventional life in urban. Male and female youth are dragged into this phenomenon that require a new way of life in urban. Nowadays, on-line business and on-line shopping have changed the usual purchasing culture in urban that have directly affect the role of manpower in many industries. Urban youth regardless of their socio-demographic are facing these challenges and they require new skills to survive in urban.

\section{Conclusion}

The increase in the urban population, especially the youths, makes the government need to find effective alternatives to overcome the problem of urban poverty among buyers more effectively. Among the efforts that need to be done is to formulate national policies that focus on the basic needs of life such as the National housing policy which emphasizes on affordable housing among the youth. In addition, improving infrastructure and public transport is also a priority to gain access to safe transportation. Programs related to youth development through personal involvement in the employment sector are also important in increasing the productivity of the country. Relevant parties need to improve survival skills by planning and designing appropriate programs taking into account gender and ethnic aspects to ensure that these programs can be used in various genders and ethnicities of youth.

\section{Reference}

Argent, N., \& Walmsley, J. I. M. (2008). Rural youth migration trends in Australia: An overview of recent trends and two inland case studies. Geographical Research, 46(2), 139-152.

Ates, H., and Alsal, K. (2012). The importance of lifelong learning has been increasing Procedia - Social and Behavioral Sciences, 46: 4092 - 4096.

Catalano, R. F., Berglund, M. L., Ryan, J. (2004). Positive youth development in the United States: Research findings on evaluations of positive youth development programs. Ann Am Acad Pol Soc Sci.591:98-124

De Sousa, A., \& De Sousa, A. (2008). An open randomized trial comparing disulfiram and naltrexone in adolescents with alcohol dependence. Journal of Substance Use, 13(6), 382-388.

Carlo, D. P., Bt. Ali, D. K. (2018). Satu Sorotan Literatur Tentang Penglibatan Sosial Belia Berstatus Sosio- Ekonomi Rendah [A Literature Highlighst on the Social Involvement of Socio-Low Status Youth]. Journal of Borneo-Kalimantan. Vol 4(1) 2018.

EACEA (Eurydice and Policy Support Unit (P9) of the Education, Education, Audiovisual and Culture Executive Agency). European Commission. (2013). Youth Social Exclusion and Lessons from Youth Work-Evidence from Literature and Survey.Diakses pada 18 Julai, 2016darip0adahttp://eacea.ec.europa.eu/youth/tools/documents/social_exclusion_a nd_youth_work.pdf.

Fernandes-alcantara, L. A. (2012). Youth and the Labour Force: Background and Trends. Congressional Research Service 7-5700, R42519. CRS Report for Congress, prepared for Members and Committees of Congress.

Gautam, S. (2016). Need of Soft Skills for Undergraduate Urban Youth for Career Development. Journal of Training and Development, Volume 2. DOI: http://dx.doi.org/10.3126/jtd.v2i0.15441.

Hair, J. F., Black, W. C., Babin, B. J., \& Anderson, R. E. (2010). Multivariate Data Analysis (7th Edition). Englewood Cliffs, NJ: Prentice Hall. 
Heisel, M., \& Flett, G. (2004). Purpose in Life, Satisfaction with Life, and Suicide Ideation in a Clinical Sample. Journal of Psychopathology and Behavioral Assessment. 26. 127-135. 10.1023/B:JOBA.0000013660.22413.e0.

Lam, S.-f., Jimerson, S., Kikas, E., Cefai, C., Veiga, F. H., Nelson, B., . . Z Zollneritsch, J. (2012). Do girls and boys perceive themselves as equally en- gaged in school? The results of an international study from 12 countries. Journal of School Psy- chology, 50, 77-94. doi:10.1016/j.jsp.2011.07.004.

Macdonald, G., \& Sirotich, F. (2005). Violence in the social work workplace: The Canadian experience. International social work, 48(6), 772-781.

Mashitah, S., Nizah, M. A., Munira, M. A., Roslizawati, M. R., Khatijah, O., Suhailiza, M. H. (2018). Religious Knowledge and Understanding among Malay Youth in Klang Valley. Jurnal Sultan Alauddin Sulaiman Shah Special Issue.

McKnight, C. G., Huebner, E. S., \& Suldo, S. M. (2002). Relationships among stressful life events, temperament, problem behavior, and global life satisfaction in adolescents. Psychology in the Schools, 39, 677-687.

M. M. Alsubaie, H. J. Stain, L. A. D. Webster \& R. Wadman (2019) The role of sources of social support on depression and quality of life for university students, International Journal of Adolescence and Youth, 24:4, 484-496, DOI: 10.1080/02673843.2019.1568887.

Mustari, M. (2005_. Menjadi belia cemerlang: belia adalah aset negara yang perlu digilap potensi mereka [Being excellent youth: youth is a national asset that needs to be polished to their potential]. Kuala Lumpur: PTS Professional.

Pallant, J. (2001). SPSS survival manual A step by step guide to data analysis using SPSS for Windows version 10. Buckingham Open University Press.

Puspakumara, J. (2011). Effectiveness of life-skills training program in preventing common issues among adolescents: community based quasi experimental study (ALST). Presentation, Dept. of Psychiatry Faculty of Medicine \& Allied Sciences Rajarata University of Sri Lanka.

Ramesht, M., \& Farshad, C. (2006). Study of life skills training in prevention of drug abuse in students. Lecture, The 3rd Seminar of Students Mental Health; Iran University of Science and Technology; Persian.

Roodbari, Z., Sahdipoor, E., \& Ghale, S. (2013). The Study of the Effect of Life Skill Training On Social Development Emotional And Social Compatibility Among First- Grade Female High School In Neka City. Indian Journal of Fundamental and Applied Life Sciences, Vol. 3(3), 382-390. Retrieved from http://www.cibtech.org/jls.htm.

Saenz, V. B., Hurtado, S., Barrera, D., Wolf,D., Yeung, F. (2007). first in my family: a profile of forst-generation college students at four-year institutions since 1971. Washington: The Foundation for Independent Higher Education.

Samsudin, A. R. (2007). Generasi belia: satu cetusan pandangan [Youth generation: a spark of views]. Putrajaya: Institut Penyelidikan Pembangunan Belia Malaysia (IPPBM).

Chaudhary, S., \& Mehta, B. (2012): Life Skill Education for the economically backward adolescent boys and girls: An Intervention Programme, International Journal of Social Sciences \& Interdisciplinary Research, 1(5).

Siwar, C., Ahmed, F., Bashawir, A., \& Mia, M. (2016). Urbanization and Urban Poverty in Malaysia: Consequences and Vulnerability. Journal Applied Science 16(4), 154160.Suryawati, C. 2005. Memahami kemiskinan secara multidimensional. Jurnal Manajemen Pelayanan Kesehatan, 121-129.

Spencer, H. (1976). Survival of the fittest. New York : Appleton. 
Suldo, S. M., \& Huebner, E. S. (2004). Does life satisfaction moderate the effects of stressful life events on psycho-pathological behavior during adolescence? School Psychology Quarterly, 19, 93-105. 